\title{
A Multidimensional, Comparative Analysis of the Regional Entrepreneurship Performance in the Central and Eastern European EU Member Countries
}

\author{
László Szerb, Éva Komlósi, and Balázs Páger
}

\section{Introduction: Entrepreneurship and Its Measure}

Entrepreneurship research has changed considerably over the last 30 years, and today entrepreneurship is widely accepted as a major driving force of economic development, of the creation of employment and of innovation (Acs et al. 2008, 2009; Carree and Thurik 2003; Braunerhjelm et al. 2010; Lazear 2004). However, the dynamics of the effect of entrepreneurship are very diverse and depend on many factors such as the development level of the home country and the institutional context (Acs et al. 2008). Whilst previous studies on entrepreneurship have focused on examining the role of entrepreneurial activity and start-up rates, recent research

\footnotetext{
L. Szerb (殴

Faculty of Business and Economics, Department of Management Sciences, University of Pécs, Pécs, Hungary

Regional Innovation and Entrepreneurship Research Center (RIERC), University of Pécs, Pécs, Hungary

e-mail: szerb@ktk.pte.hu

É. Komlósi

MTA-PTE Innovation and Economic Growth Research Group, University of Pécs, Pécs, Hungary

Regional Innovation and Entrepreneurship Research Center (RIERC), University of Pécs, Pécs, Hungary

e-mail: komlosieva@ktk.pte.hu

B. Páger

Institute for Regional Studies Centre for Economic and Regional Studies, Hungarian Academy of Sciences, Budapest, Hungary

Regional Innovation and Entrepreneurship Research Center (RIERC), University of Pécs,

Pécs, Hungary

e-mail: pagerb@rkk.hu
} 
has shown that not all entrepreneurial activity is effective. High growth rates, such as those achieved by innovative gazelle companies, are responsible for the bulk of new job creation and growth, whilst other non-innovative or traditional businesses have only minor economic influence (Acs and Mueller 2008; Baumol 1996; Wong et al. 2005).

The other major breakthrough of entrepreneurship research was the recognition of the environmental factors in venture creation and, ultimately, on growth and development. The design and implementation of successful entrepreneurial startups require attention, not only to individual and firm-specific strengths and weaknesses but also to the wider institutional context within which the new ventures operate (Henrekson and Johansson 2011; Zahra and Nambisan 2011). Most recently, entrepreneurship researchers have acknowledged that the individual elements of the environment should not be interpreted in isolation from each other. In fact, the entrepreneurial ecosystem of a country or region comprises a system of mutually dependent factors (Furerlinger et al. 2014; Stangler and Bell-Masterson 2015).

Whilst the conceptualization and contextualization of entrepreneurship have developed rapidly, research into measuring within the topic has lagged behind. According to Acs et al. (2014), there are three major lines of approach which should be adopted, and these are output, attitude and framework. If entrepreneurship is defined as a start-up or existing business and quantified by output measures such as self-employment, total early-stage entrepreneurial activity (TEA) or business density data, then entrepreneurship is positively correlated with short-term growth, but negatively with economic development as reflected in GDP per capita (Shane 2009; Szerb et al. 2013). A declining trend of 'output-to-development' rate is a frequent product of empirical studies (Carree et al. 2002; Noseleit 2013; Wennekers and Thurik 1999), and these findings underline the fact that not all entrepreneurship is good (Baumol 1996) and there is a place for alternative ways to measure entrepreneurship other than simple indicators (Stenholm et al. 2013).

Measuring attitudes is even more problematical since this is based on a survey of perceptions, attitudes and beliefs, which may or may not lead to a business being started (Acs et al. 2014). Framework measuring, with the help of tools such as the World Bank's 'Ease of Doing Business' or the Heritage Foundation's 'Economic Freedom Index', captures at least part of the entrepreneurial (regulatory) framework, but tells us little or nothing about the type of activity emerging in a particular framework context (Acs et al. 2014). We believe that the entrepreneurial performance of a given region can be measured and interpreted by examining the individual elements of the institutional framework together with the interaction between them.

The Global Entrepreneurship Index (GEI) approach—which we intend to use here-is based on three important premises which provide an appropriate platform for analysing entrepreneurial ecosystems. Firstly, entrepreneurship is fundamentally action undertaken and driven by agents - and so individual level data is needed to show the dynamics of an entrepreneurial ecosystem. Secondly, individual action is controlled by an institutional framework for entrepreneurship-and so 
relevant institutional level data are also needed for the same purpose. Thirdly, such ecosystems are complex, multifaceted structures in which many elements interact to enable the systems to function, and so the index method needs to allow these elements to interact. This novel index building approach also makes it possible to identify the strengths and weaknesses of a particular geographical unit and to provide tailor-made rather than uniform solutions to the problems of how to develop entrepreneurship.

Recent research reinforces the view that the distribution of entrepreneurial activity and entrepreneurship are spatially unbalanced (Acs 2010; Audretsch and Fritsch 2002; Fritsch and Schmude 2006; Feldman 2001; Sternberg 2011). Our emphasis on the controlling influence of the institutional context implies that entrepreneurship is best studied at levels which transcend the individual decision to involve oneself in such activity. Whilst many rules and regulations may exist at national level, there are other related contexts such as human capital, finance, education, networking/clustering, innovation, etc., in which a level below the national is more appropriate (Feldman 2001; Stam 2007; Sternberg 2011; Henrekson and Johansson 2011; Westlund and Bolton 2003; Kerr and Nanda 2009). The Regional Entrepreneurship and Development Index (REDI) methodology is based on the GEI, which measures entrepreneurship at country level. This latter index has now been implemented for measuring the entrepreneurial performance of a mixture of 125 NUTS1 and NUTS2 EU regions, a process which includes changes to the environmental and institutional variables to reflect the regional forces of agglomeration, connectivity and clustering (Komlósi et al. 2015).

This paper focuses on an examination of the entrepreneurial performance of the Central and Eastern European (CEE) regions by applying the REDI. The relevance of the topic is highlighted by the fact that regional entrepreneurship has not yet, to the best of our knowledge, been seriously investigated in the CEE countries. Since regional disparities have drastically increased since the start of the transition in many CEE countries (Sokol 2001; Blažek and Netrdová 2012), it is worth investigating the connection between the differences in levels of development and of entrepreneurship. Since REDI is designed to explain development, we expect that CEE country and regional differences are also, at least partially, due to differences in entrepreneurial performance. We aim to compare CEE regions to other European regions by examining their entrepreneurial profile based on the 14 pillars of entrepreneurship. Finally, we present an entrepreneurship policy portfolio for each CEE region, based on the assumption that the weakest performing elements of entrepreneurship should be improved in order to achieve maximal improvement in entrepreneurship ecosystems.

The study is structured in the following way. Firstly, in Sect. 2, we offer a brief review of the development of entrepreneurship in the context of the politicoeconomic transition in the CEE countries, and in the following part, we describe REDI methodology and the related measure procedures before examining the 29 Central and Eastern European (CEE) regions. We next compare these CEE regions' REDI scores with those of the other EU regions in relation to their level of development, whilst the REDI scores and the three subindices are investigated in 
comparison with two other macro-regions (Sect. 4). Our examination of the 'Fourteen Pillars' is based on a cluster analysis (Sect. 5). We then present our concept of a 'tailor-made entrepreneurship policy optimization' as a separate section-immediately prior to the conclusion of the study.

\section{Entrepreneurship in the CEE Countries}

The investigation of entrepreneurship in the transition context is relatively new, since private enterprises could only be freely established after the introduction of market economy institutions. Whilst some forms of private business existed even in the planned economy, their operations were closely monitored and strictly regulated (McMillan and Woodruff 2002). After the transition, the regulations and economic environment changed to provide a favourable environment for individuals to start their own business (Kornai 2006). Czech Republic, Poland, Hungary and Slovenia played leading roles in this, and their economies performed better than other transition economies. Later, Slovakia and the three Baltic states caught up to these countries (Szerb and Trumbull 2016). The 1990s saw an 'entrepreneurial boom' in the CEE countries, fuelled by the high demand for normal consumer goods and by the increased supply of labour due to rising unemployment and the privatization of existing businesses (Kornai 1992; Tyson et al. 1994). Institutions and private and public agencies also played a role in supporting de novo business start-ups (Bateman 2000; Smallbone and Welter 2001), although many of these new businesses were unproductive or destructive (Sauka 2008). At the same time, innovative, productive entrepreneurship was lacking in all CEE countries (Smallbone and Welter 2001).

By the late 1990s, the situation of the CEE transition countries had changed: Privatization had come to an end and basic market economy institutions were operating. Markets were quickly saturated as shortages disappeared. The further opening of the domestic market to foreign businesses intensified competition, resulting in shrinking local market opportunities and a declining rate of business activity (Szerb and Trumbull 2016). This change was further strengthened by EU Accession in 2004 and the related opening of the domestic markets. The lack of productive, entrepreneurial ventures became obvious, calling for further institutional changes and refinements (Chepurenko 2015; Estrin et al. 2006; Smallbone and Welter 2012). However, policy makers also had to take into account the fact that, besides formal institutions, informal institutions, attitudes, social norms andin general-trust are also highly important factors in the development of entrepreneurship in these countries (Estrin and Mickiewicz 2011).

The economic crisis starting in 2007 exposed the weaknesses of small business and entrepreneurship development in the transition context. According to van der Zwan et al. (2011), European transitional country entrepreneurial progress was greatly hindered by perceived environmental constraints such as the administrative complexity of business start-ups. However, recovery has been very different in the 
CEE countries, underlining the fact that these transitional countries are not homogenous (Chepurenko 2015).

\section{Measuring Regional Entrepreneurship: From Definition to Measure}

Whilst Szerb and Trumbull (2016) examined country-level entrepreneurship in transitional countries, here we turn to regional-level analysis. Following Acs et al. (2014), we define the systems of entrepreneurship as follows: 'A System of Entrepreneurship (SE) is the dynamic, institutionally embedded interaction between entrepreneurial attitudes, ability, and aspirations, by individuals, which drives the allocation of resources through the creation and operation of new ventures' (Acs et al. 2014, p. 119). REDI is created to measure SE in a regional context. This definition implies that REDI conceptualizes entrepreneurship as a trial-and-error process of knowledge spillovers and resource allocation which is driven by individuals and regulated by context and which drives the allocation of resources towards productive use in the economy (Qian et al. 2013).

With the creation of the REDI, our main objectives were (1) to identify the crucial regional drivers of the entrepreneurial 'discovery' process, (2) to emphasize the system characteristics of these identified drivers, (3) to find adequate regional (or country level) variables and proxies and (4) to provide a useful tool to analyse alternative entrepreneurship policy scenarios. This is why the REDI was designed to incorporate 14 different pillars, each created as a product of individual- and institutional-level data. A careful scrutiny of the relative differences between individual pillars, both within a given region and across benchmark regions, should provide good initial guidance for the search for prospective strengths and weaknesses across regions.

The GEI indicators, which use country-level institutional and individual (survey) data, should be modified to reflect regional conditions, and so, in addition to country-level data, the indicators now include regional institutional and individual variables also. Regional level variables show the local spillover effects of agglomeration (size of region, market potential), connectivity, networking/clustering, social capital, education systems, human capital, the effects of knowledge spillover and innovation, the role of regulation, the quality of governance and also of finance.

We propose a six-level index-building process: (1) subindicators, (2) indicators, (3) variables, (4) pillars, (5) subindices and, finally, (6) the super index. The most important building blocks are the 14 pillars which contain, simultaneously, regional individual, regional and country-level institutional variables. These pillars comprise three subindices: entrepreneurial attitudes (five pillars), abilities (four pillars) and aspirations (five pillars). Regional and country-level variables are drawn from different database and the variables from 40 indicators. Some institutional 


\begin{tabular}{|c|c|c|c|}
\hline \multicolumn{2}{|c|}{$\begin{array}{l}\text { Structure of the REDI } \\
3 \text { Sub-indexes } \\
14 \text { Pillars } \\
28 \text { Variables }\end{array}$} & $\begin{array}{l}\text { National and regional } \\
\text { institutional variables }\end{array}$ & $\begin{array}{l}\text { Regional level } \\
\text { individual variables }\end{array}$ \\
\hline \multirow{5}{*}{$\begin{array}{l}\text { Entrepreneurial } \\
\text { Aspiration } \\
\text { Sub-index }\end{array}$} & Financing & FINANCIAL INSTITUTIONS & INFORMAL INVESTMENT \\
\hline & Globalization & CONNECTIVITY & EXPORT \\
\hline & High growth & CLUSTERING & GAZELLE \\
\hline & Process innovation & TECHNOLOGY DEVELOPMENT & NEW TECHNOLOGY \\
\hline & Product innovation & TECHNOLOGY TRANSFER & NEW PRODUCT \\
\hline \multirow{4}{*}{$\begin{array}{l}\text { Entrepreneurial } \\
\text { Ability } \\
\text { Sub-index }\end{array}$} & Competition & BUSINESS STRATEGY & COMPETITORS \\
\hline & Human capital & EDUCATION \& TRAINING & EDUCATION LEVEL \\
\hline & Technology sector & ABSORPTIVE CAPACITY & TECHNOLOGY LEVEL \\
\hline & Opportunity start-up & BUSINESS ENVIRONMENT & OPPORTUNITY MOTIVATION \\
\hline \multirow{5}{*}{$\begin{array}{l}\text { Entrepreneurial } \\
\text { Attitudes } \\
\text { Sub-index }\end{array}$} & Cultural support & OPEN SOCIETY & CAREER STATUS \\
\hline & Networking & SOCIAL CAPITAL & KNOW ENTREPRENEURS \\
\hline & Risk acceptance & BUSINESS RISK & RISK PERCEPTION \\
\hline & Startup skills & QUALITY OF EDUCATION & SKILL PERCEPTION \\
\hline & Opportunity perception & MARKET AGGLOMERATION & OPPORTUNITY RECOGNITION \\
\hline
\end{tabular}

Fig. 1 The structure of the Regional Entrepreneurship and Development Index

indicators are complex creations in themselves, comprising 76 subindicators in total (for more details, see Szerb et al. 2014) (Fig. 1).

The entrepreneurial attitude (ATT) subindex aims to identify the attitudes of a region's population as they relate to entrepreneurship. The entrepreneurial abilities (ABT) subindex is principally concerned with measuring certain important characteristics of both entrepreneur and start-up with high growth potential. The entrepreneurial aspiration (ASP) subindex refers to the distinctive, qualitative, strategyrelated nature of entrepreneurial start-up activity. ${ }^{1}$

REDI provides serious guidance for creating conditions in which a region's entrepreneurial dynamics function efficiently and can be used as a platform which facilitates the design of effective tailor-made development policies in EU regions. However, any regional system of entrepreneurship would necessarily be much more complex than an index such as the REDI could fully capture.

Our index incorporates both individual-level and institutional variables. The former are based on indicators from the Global Entrepreneurship Monitor (GEM) Adult Population Survey dataset, and for present purposes, we have used the 2007-2011 pooled GEM data. Since the GEM dataset lacks the necessary institutional variables, we complemented it for the index with other widely used and relevant data derived from a variety of sources available as of December 31, 2013.

\footnotetext{
${ }^{1}$ A more detailed description of the pillars can be found: Szerb et al. (2014), REDI: The Regional Entrepreneurship and Development Index-Measuring regional entrepreneurship. Final report. European Commission, Directorate-General for Regional and Urban policy, Luxemburg (Appen$\operatorname{dix} \mathrm{A}$ and $\mathrm{C})$.

http://ec.europa.eu/regional_policy/information/studies/index_en.cfm\#1 (September 25, 2014).
} 


\section{Entrepreneurial Performance and Economic Development in the CEE Regions}

According to the REDI methodology ${ }^{2}$ described in Appendix, we have calculated the REDI scores for 125 regions of 24 EU countries (Table 1).

The REDI scores can vary from zero to a hypothetical maximum of 100 . In our case, REDI scores range from 18.4 to 82.2. According to Table 1, the variations in entrepreneurship over the 125 regions are substantial-more than fourfold. The top performing regions in Europe are located in the Scandinavia and in Western Europe. The REDI scores confirm that European capital cities and highly urbanized regions show outstanding entrepreneurial performance. Amongst the best performing regions, there are only a few which do not include a capital, and even these regions have important national functions.

As mentioned previously, the REDI index is designed to examine the role of entrepreneurship in economic development. According to Fig. 2, there is a close connection between entrepreneurship and regional development (measured by GDP per capita). The third-degree polynomial adjustment explains $56 \%$ of the variations between entrepreneurship and economic development, showing a moderately strong connection between the REDI and per capita GDP.

Table 2 shows the REDI scores, the development-implied REDI scores (calculated from the third degree polynomial equation) and the deviation between the actual and the development-implied REDI scores for the 29 CEE regions.

Table 2 provides us a more nuanced picture of the level of entrepreneurship in the CEE country regions as compared to the rest of the EU. Whilst the average deviation from the development-implied trend line is -1.2 for the 29 CEE regions, it is +0.4 for the other EU regions. This means that CEE regions' entrepreneurial performance is, on average, below the development-implied trend line as compared to the other 94 EU regions. Whilst more developed, mainly capital city, regions in the CEE countries have higher REDI scores than less developed regions, their actual REDI scores are still further below the development implied trend line as compared to less developed CEE regions. For example, Bratislavský kraj, with the highest 43,100 euros per capita GDP in the CEE region, should have a 66.4 REDI score rather than the actual 44.0 value. At the same time, Estonia has a 45.9 REDI score, whilst it is only 32.6 which we should expect based on the development of the country region.

\footnotetext{
${ }^{2}$ Detailed description of the REDI methodology can be found: Szerb et al. (2014), REDI: The Regional Entrepreneurship and Development Index-Measuring regional entrepreneurship. Final report. European Commission, Directorate-General for Regional and Urban policy, Luxemburg, p. $30-46$.

http://ec.europa.eu/regional_policy/information/studies/index_en.cfm\#1 (September 25, 2014).
} 


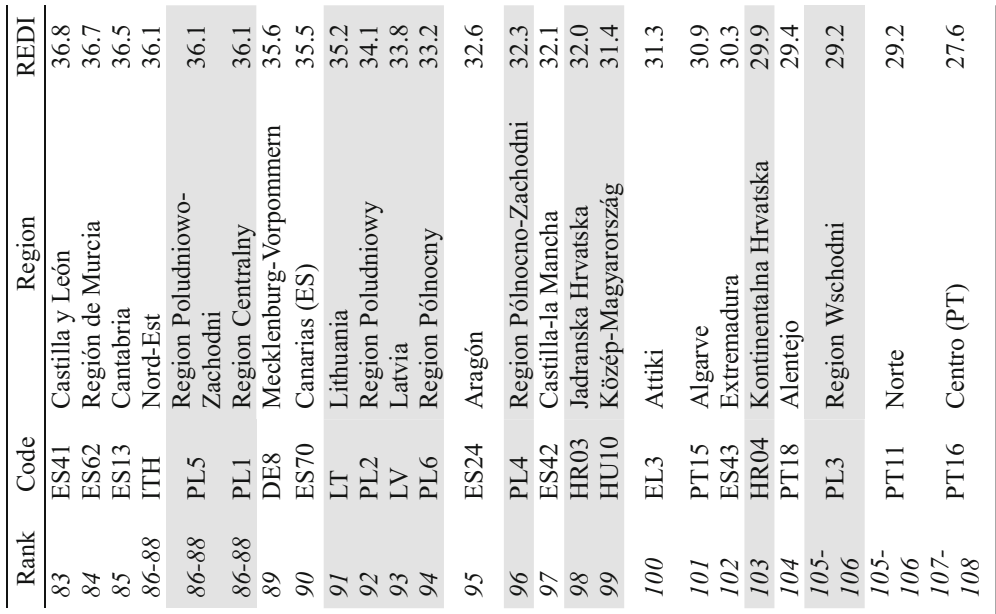

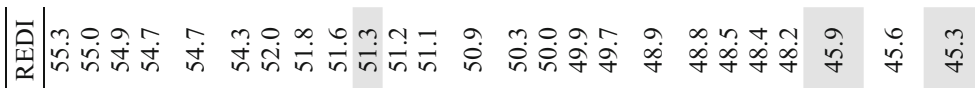

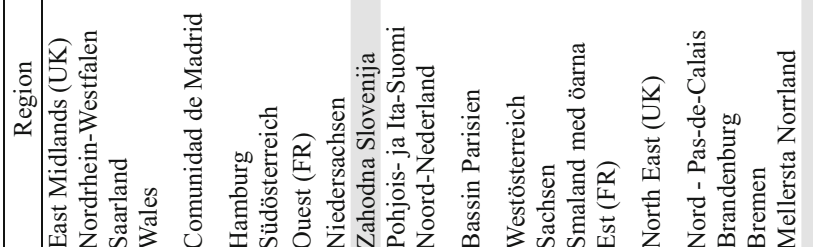

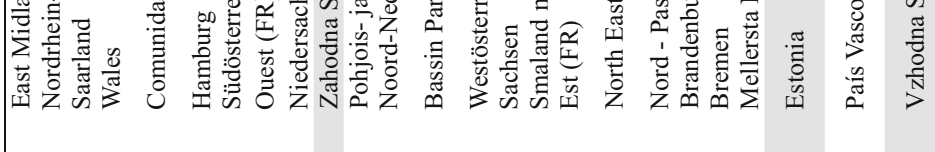

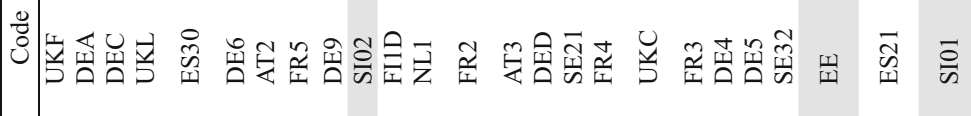

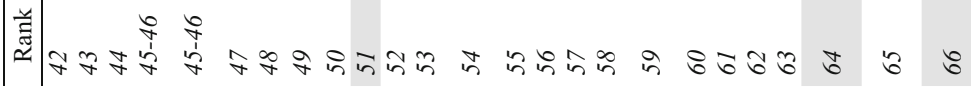

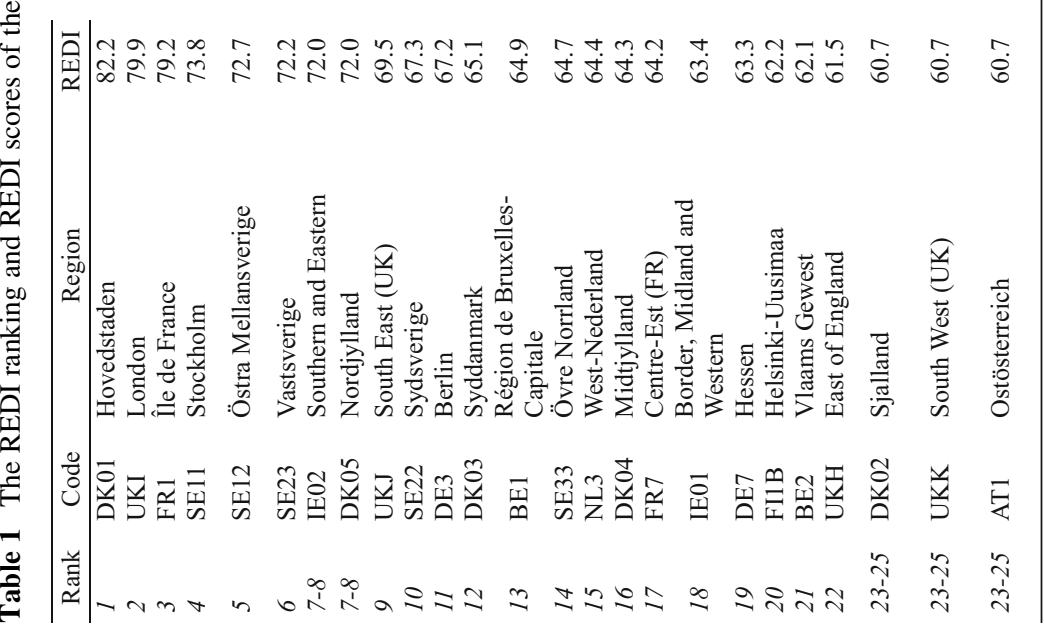




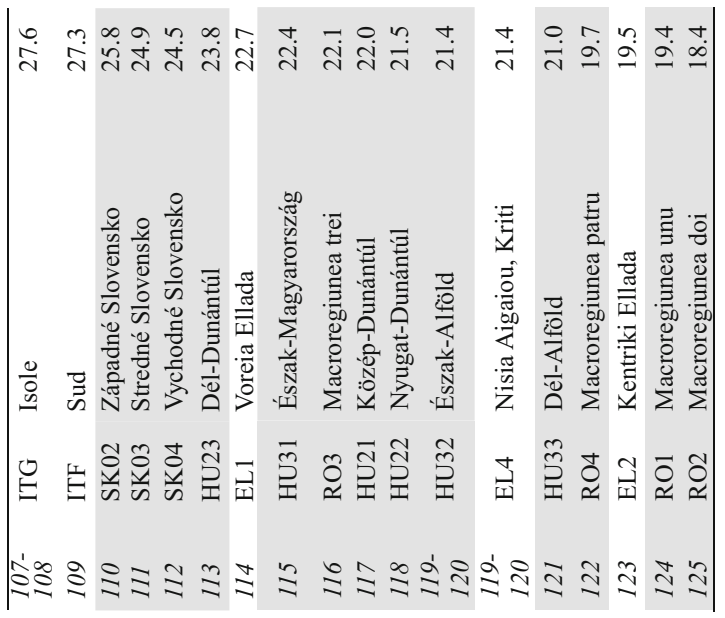

|

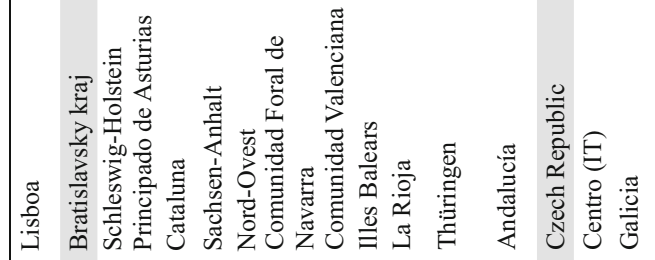

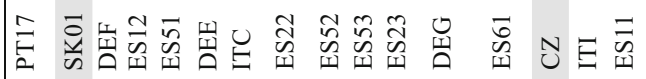

๑

|

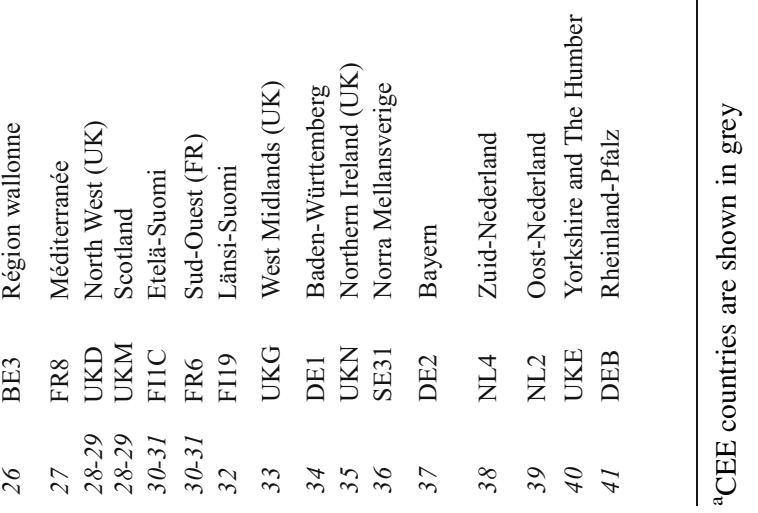




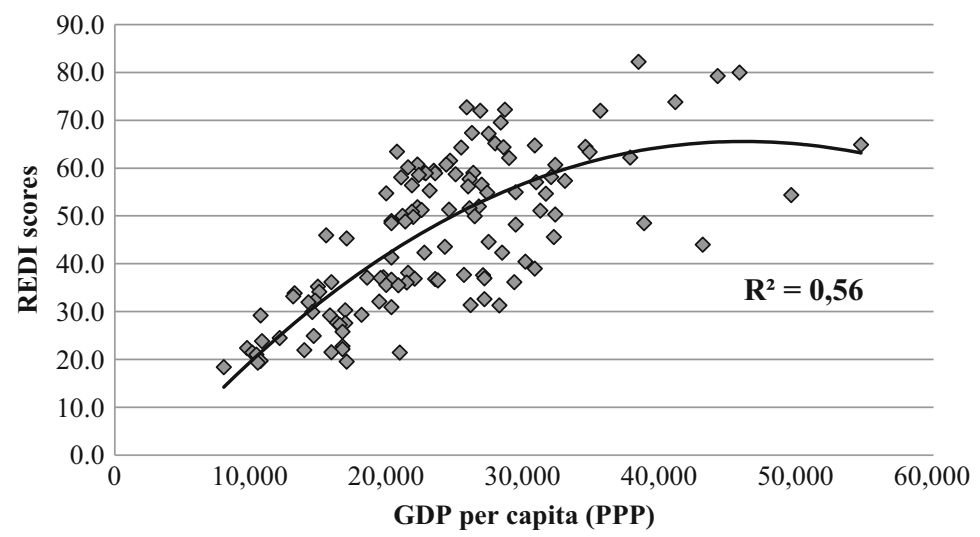

Fig. 2 The connection between REDI scores and economic development. Notes: Third degree of polynomial adjustment. Number of observations $=125$

\section{Subindex and Pillar Level Analysis}

For further analysis, we created three macro-regions. The Northern and Western Europe (NWE) macro-region consists of Scandinavian, United Kingdom, Irish, German, Dutch, Belgian and French regions (65 regions). The Southern Europe (SE) macro-region contains Spanish, Portuguese, Italian and Greek regions (31 regions), whilst Central and Eastern Europe (CEE) includes 29 regions. Besides these three macro-regions, we also present the best and the worst entrepreneurial regions, which are the Danish Hovedstaden Central region with 82.2 REDI points and the Romanian Macroregiunea doi with only 18.4 points (Table 3). The average REDI score of the NWE regions is 58.5, which is significantly higher than the SE (average 34.7) and CEE regions' (average 30.1).

Whilst aggregated index scores can illustrate the overall differences amongst the particular country groups, they tell us nothing about the strong and the weak constituents of the performance. This is the reason why we have to examine the components of the REDI scores-the subindices and the pillars. According to Table 3, the SE and CEE regions lag behind the NWE regional average in all three subindices, although the NWE and SE regions have similar scores in all three. At the same time, however, the CEE regions are less balanced. CEE countries have the lowest scores in entrepreneurial abilities (23.3), but their average entrepreneurial aspirations score (37.6) is higher than that of the SE countries. The leading Danish capital city region (DK01) has an outstanding performance in almost all of the subindices. Similar to the CEE averages, the Romanian region (RO2) performs relatively well only in entrepreneurial aspiration, but it lags behind the CEE regional averages in all three subindices.

Figure 3 shows the pillar values of the three macro-regions. These reinforce the fact that the NWE macro-region generally performs better than the SE or CEE regions. The NWE region's superiority regarding pillars related to entrepreneurial 


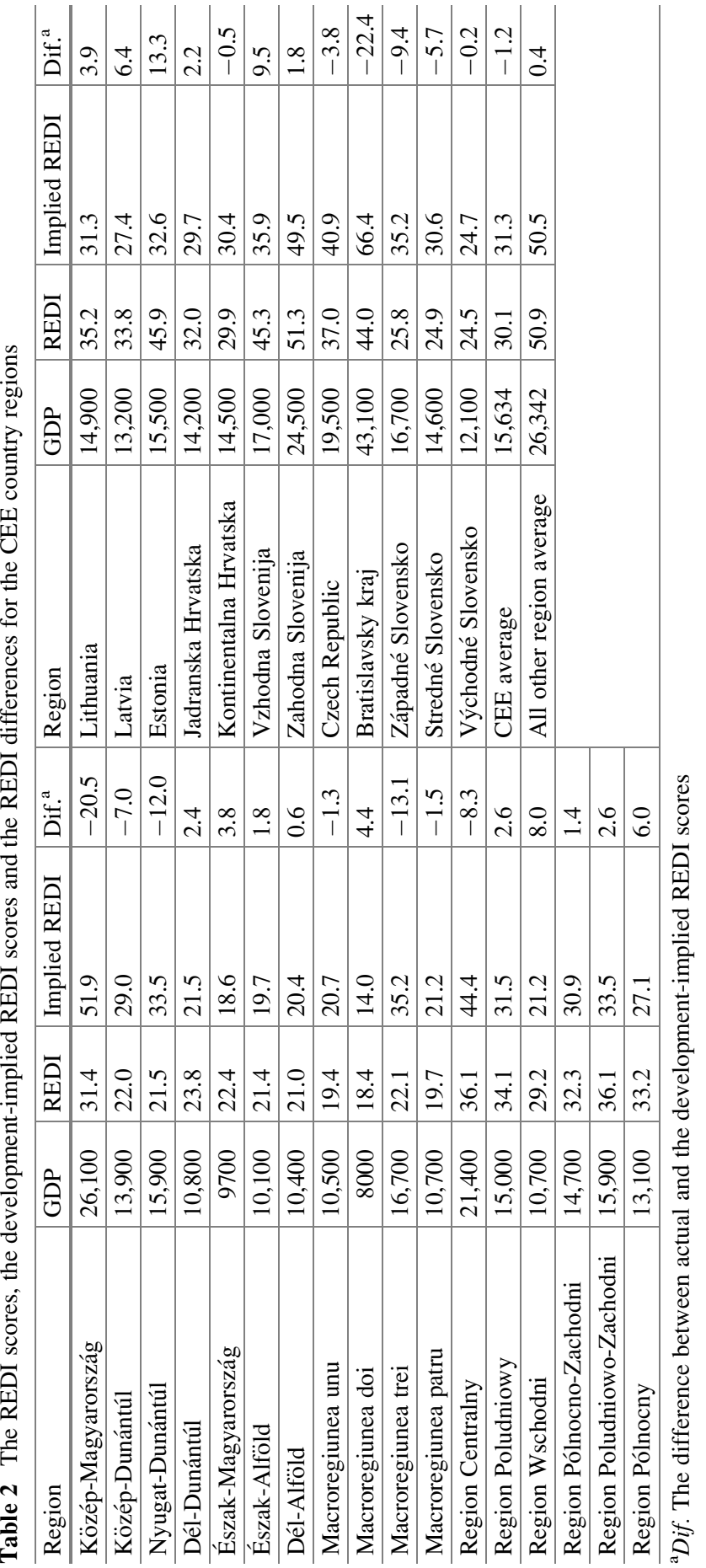


Table 3 Comparison of REDI and subindex scores of the three European macro-regions

\begin{tabular}{l|l|l|l|l}
\hline Region & $\begin{array}{l}\text { Entrepreneurial } \\
\text { attitudes (ATT) }\end{array}$ & $\begin{array}{l}\text { Entrepreneurial } \\
\text { abilities (ABT) }\end{array}$ & $\begin{array}{l}\text { Entrepreneurial } \\
\text { aspirations (ASP) }\end{array}$ & REDI \\
\hline DK01, Hovedstaden & 79.7 & 89.6 & 77.2 & 82.2 \\
\hline $\begin{array}{l}\text { Northern and Western } \\
\text { European regions (NWE) }\end{array}$ & 59.5 & 61.6 & 54.5 & 58.5 \\
\hline $\begin{array}{l}\text { Southern European } \\
\text { regions (SE) }\end{array}$ & 33.8 & 35.4 & 35.0 & 34.7 \\
\hline $\begin{array}{l}\text { Central and Eastern } \\
\text { European regions (CEE) }\end{array}$ & 29.5 & 23.3 & 37.6 & 30.1 \\
\hline RO2, Macroregiunea doi & 19.7 & 10.3 & 25.2 & 18.4 \\
\hline
\end{tabular}

Fig. 3 Comparison of the entrepreneurial profile of the three macro-regions

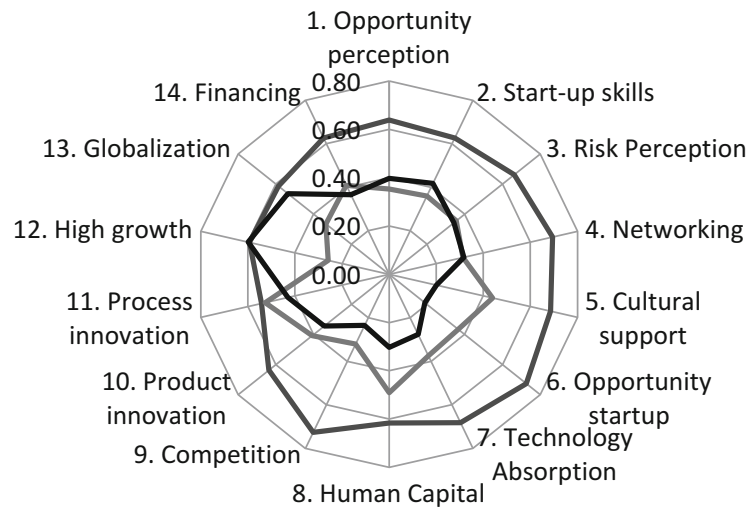

Northern and Western Europe

South Europe

Central and Eastern Europe

attitude and ability is fairly clear. A narrower gap between the macro-regions can only be seen in some pillars of entrepreneurial aspiration. For example, SE regions are close to NWE regions regarding the Process Innovation pillar, whilst CEE regions have marginally better (high growth) or similar (globalization) performance than NWE regions in two cases. Whilst the REDI average scores of the SE and CEE countries do not differ too much, their entrepreneurial profiles are not similar in terms of the fourteen pillars. The entrepreneurial attitude pillar scores-except for the cultural support pillar-are near to each other with slightly better performances of the SE countries. However, SE countries are clearly better than CEE countries in all entrepreneurial abilities pillars (opportunity start-up, technology absorption, human capital and competition) and the two innovation pillars belonging to the entrepreneurial aspiration subindex (product innovation and process innovation). At the same time, CEE countries have higher scores in high growth and globalization than SE countries. Both groups have nearly equal pillar scores in finance. 


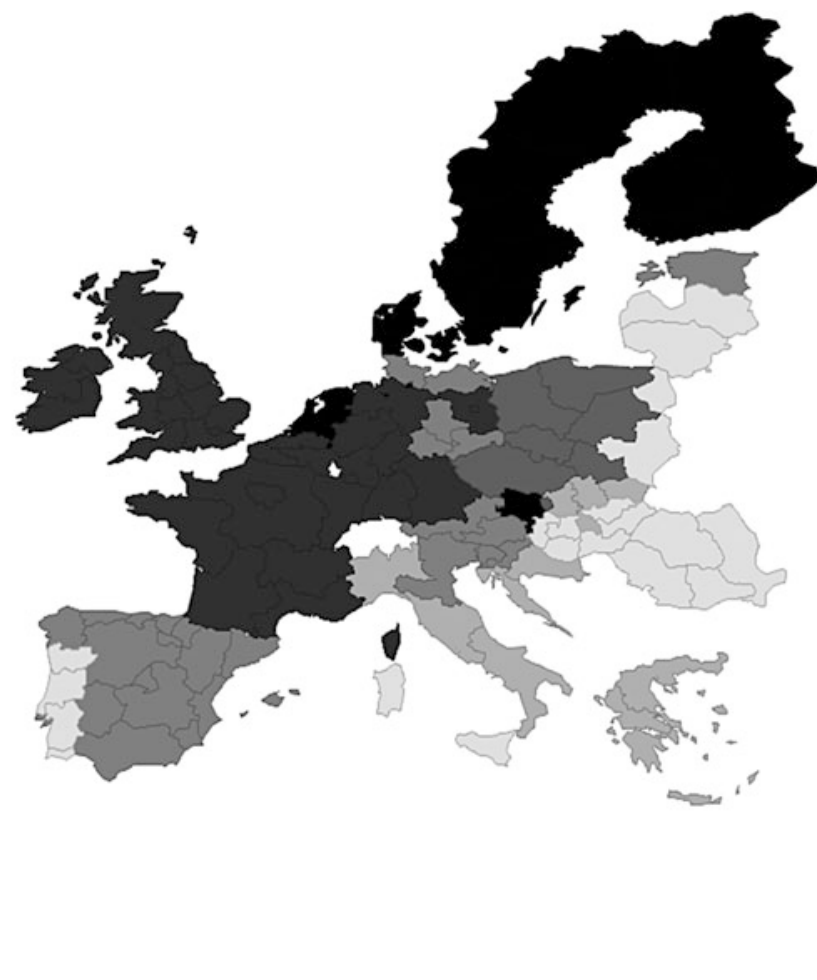

Fig. 4 The clusters of the European Union regions based on the fourteen pillars (K-means cluster). Note: The darker colours show high performance regions and the lighter colours lower performance

As shown, the overall entrepreneurial performance of the CEE regions is below that of the other two macro-regions. The differences increase if we examine the three sub-indices of the three macro-regions. We expect even more substantial differences amongst the 29 CEE regions if the examination is based on the 14 pillars. In order to examine these deviations within the CEE country group, we conducted a K-means clustering exercise. Figure 4 shows all the EU regions' clusters in six groups based on the fourteen REDI pillars. ${ }^{3}$ In addition, Table 4 shows the pillar values and the REDI scores for all six clusters.

According to Fig. 4 and Table 4, the most developed regions of the Nordic countries, Belgium, the Netherlands, France, (West) Germany, Ireland and the UK, with their high REDI scores, comprise the first two clusters. The CEE country regions-with their lower scores-belong to the remaining four clusters. The three leading CEE regions, (Zahodna Slovenija, Vzhodna Slovenija and Estonia) form a

\footnotetext{
${ }^{3}$ We tried several versions, but for our purposes, the six cluster version proved to be the best. The ANOVA table confirmed that all 14 pillars are significant elements of the k-means clustering.
} 
Table 4 The pillar values and the REDI scores of the six EU clusters

\begin{tabular}{l|l|l|l|l|l|l}
\hline Clusters/pillars & 1 & 2 & 3 & 4 & 5 & 6 \\
\hline Opportunity perception & 0.88 & 0.53 & 0.38 & 0.52 & 0.35 & 0.31 \\
\hline Start-up skills & 0.73 & 0.57 & 0.45 & 0.55 & 0.37 & 0.30 \\
\hline Risk perception & 0.59 & 0.77 & 0.37 & 0.37 & 0.20 & 0.42 \\
\hline Networking & 0.92 & 0.56 & 0.42 & 0.45 & 0.28 & 0.21 \\
\hline Cultural support & 0.82 & 0.61 & 0.56 & 0.26 & 0.13 & 0.21 \\
\hline Opportunity start-up & 0.89 & 0.64 & 0.46 & 0.12 & 0.19 & 0.23 \\
\hline Technology absorption & 0.67 & 0.71 & 0.48 & 0.22 & 0.34 & 0.22 \\
\hline Human capital & 0.72 & 0.60 & 0.56 & 0.26 & 0.25 & 0.28 \\
\hline Competition & 0.66 & 0.81 & 0.39 & 0.22 & 0.28 & 0.24 \\
\hline Product innovation & 0.74 & 0.60 & 0.46 & 0.75 & 0.33 & 0.16 \\
\hline Process innovation & 0.53 & 0.58 & 0.49 & 0.52 & 0.52 & 0.40 \\
\hline High growth & 0.50 & 0.73 & 0.29 & 0.75 & 0.43 & 0.45 \\
\hline Globalization & 0.48 & 0.64 & 0.40 & 0.77 & 0.43 & 0.46 \\
\hline Finance & 0.68 & 0.58 & 0.47 & 0.59 & 0.54 & 0.17 \\
\hline REDI score & 61.4 & 59.4 & 40.9 & 36.1 & 28.3 & 25.3 \\
\hline Number of regions & 24 & 34 & 29 & 7 & 13 & 18 \\
\hline
\end{tabular}

cluster together with former East Germany and Spanish regions. The regions of this group-Cluster 3-are relatively strong in cultural support (0.56) and human capital (0.56), but weak in high growth (0.29). The average REDI score is 40.9, substantially lower than Cluster 1 (61.4) and Cluster 2 (59.4).

Cluster 4 consists only of CEE regions (Czech Republic, Bratislavský kraj and five Polish regions). These CEE regions show a somewhat contradictory picture as they are very weak in opportunity start-up (0.12) and competition $(0.22)$ but very good in globalization (0.76), high growth (0.75) and product innovation (0.75). Croatian, Slovakian regions and the Hungarian Közép-Magyarország belong to Cluster 5, together with most Greek and two Italian regions. Cultural support (0.13), opportunity start-up (0.19) and risk perception $(0.20)$ are their weak pillars. Surprisingly, finance $(0.54)$ is the highest score of these 13 regions. The least developed Hungarian and Romanian regions, Latvia and Lithuania, are found in the lowest REDI value group, similar to most Portuguese and Italian regions (Cluster 6). Product innovation (0.16) and finance (0.17) are the weakest pillars of Cluster 6, whilst the globalization (0.46) and high growth (0.45) scores are relatively high.

From these observations, we can draw four clear inferences. Firstly, CEE regions show a wide range of entrepreneurial profiles based on the 14 pillars. Secondly, most CEE regions match other EU regions' entrepreneurial profiles as only seven regions, which form Cluster 4, seem to deviate slightly from other EU regions. Thirdly, a country's own regions tend to cluster, implying that cross-border differences are greater than deviations within the same country. Fourthly, CEE regions, except for the three with the highest REDI scores, have entrepreneurial profiles similar to those of the Southern European regions of Greece, Italy and Portugal. 


\section{Tailor-Made Regional Entrepreneurship Policy Recommendations}

As detailed above, REDI is a useful tool to measure regional entrepreneurship taking into account many elements of the entrepreneurial ecosystem. Earlier in this paper, we examined the regional entrepreneurship differences of CEE country regions, based on REDI scores, the 3 subindices and the 14 pillars. We concluded that differences are substantial amongst the $125 \mathrm{EU}$ regions and also amongst the 29 CEE regions. These differences in the entrepreneurial profile call for tailor-made entrepreneurship policy, unique to each region, as opposed to a highly uniform, 'one- size-fits-all' policy.

Unlike other composite indicators, REDI is able to provide distinctive entrepreneurship policy recommendations for enhancing regional entrepreneurial performance and optimizing policy efforts. The penalty for bottleneck (PFB) methodology implies that the greatest improvement in the entrepreneurship system performance can be achieved by mitigating the weakest performing pillar-the bottleneck pillar. The basic assumption is that a system with some weaknesses cannot fully utilize its strengths. This means that weakly performing pillars hold back system performance in situations where pillars co-produce system performance. Following this logic, instead of further strengthening a strong point of the system, it would be more effective to alleviate the identified bottleneck pillars which prevent the system from fully exploiting its strengths. The system of entrepreneurship is also a dynamic system-which means that, if we alleviate one bottleneck, another pillar soon may become the most binding constraint for system performance. This raises the question of the 'optimal' allocation of additional resources. A region's system of entrepreneurship is optimized if all the 14 pillars have the same value. In this hypothetical case, improvement can be achieved by increasing simultaneously all pillars.

The following simulation seeks to identify the 'most efficient' allocation of additional resources which seeks to increase the REDI index score by five points. In order to do this, each bottleneck pillar is alleviated to a point where it ceases to be a bottleneck. At this point, any further effort is allocated together to the first and the second most binding constraints within the system, again to a point where these constraints are no longer the most binding constraints within the system. This exercise is continued until the desired aim, currently the five-point increase in the REDI score, has been achieved. We have conducted a series of simulations for all 125 European regions, but here we show and analyse only the outcomes of the CEE regions. This simulation is based on two important assumptions: (1) We allocate additional resources over the current resource allocation, and (2) the cost of improving performance is equal for all pillars. Even if the assumptions are restrictive and should be so regarded, the policy portfolio simulation offers many benefits which go above and beyond what traditional indices can offer.

Table 5 shows the result of this optimization exercise for all 29 CEE regions. The numbers in any row represents the percentages of resources necessary to add to the 


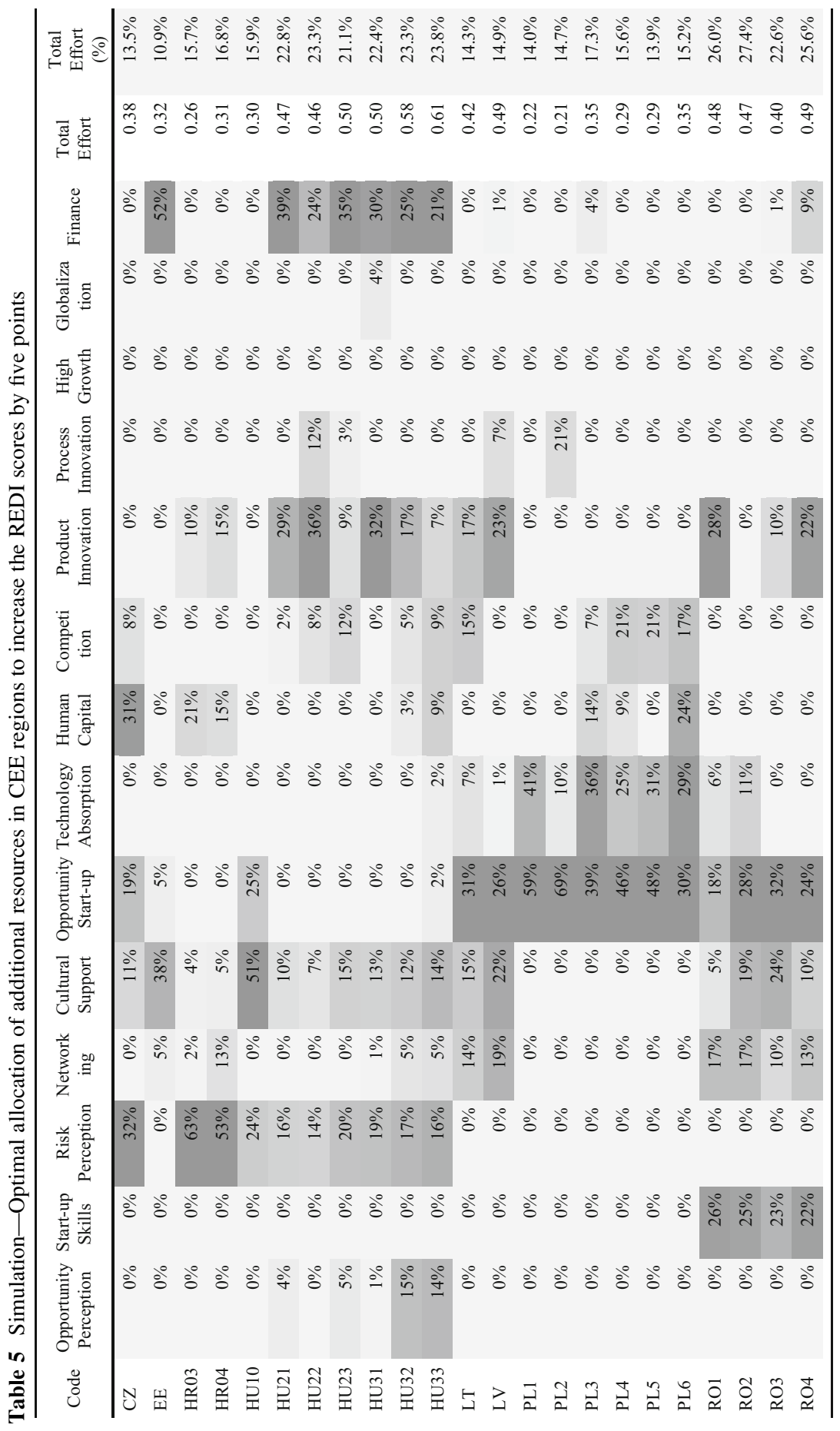




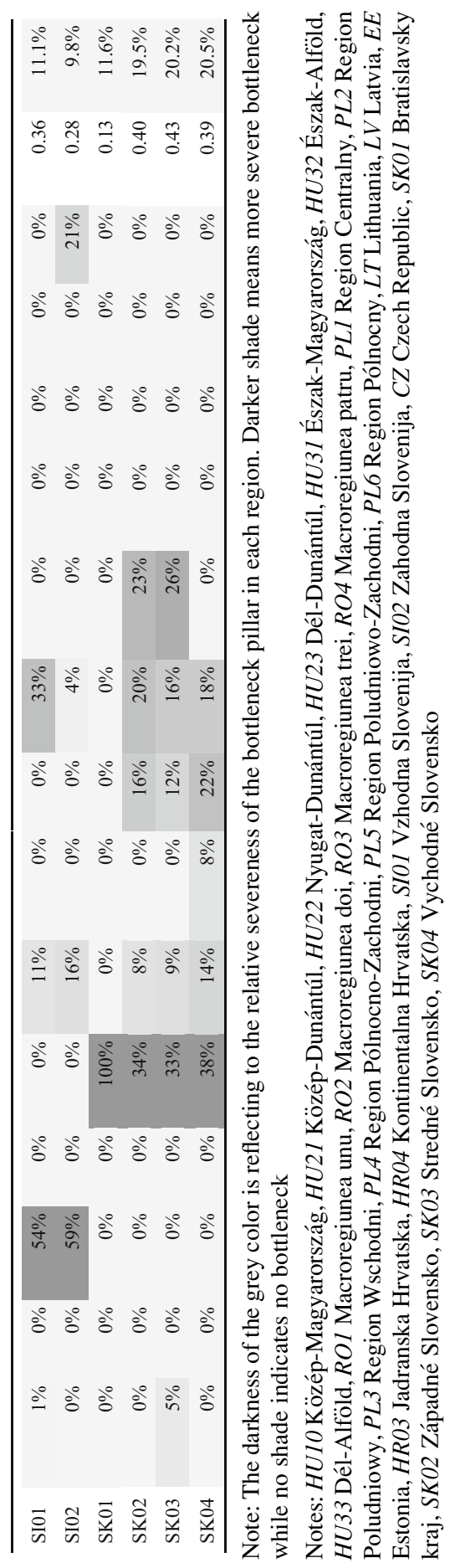


particular pillar value in order to reach the required alleviation of the bottleneck pillar. Zero value indicates that the pillar is currently not a binding constraint for that region. The total effort column provides the overall sum of the required resources. Larger numbers indicate that more resources are necessary for overall performance improvement in a given region. In the last column, we show the percentage increase of the total resources (the sum of the 14 pillars) necessary for the five-point increase of the REDI scores, assuming optimal resource allocation.

The simulation produces a more nuanced picture of the required allocation of policy effort. Different regions require different policy efforts depending on the size and the magnitude of the bottleneck. Bratislavsky Kraj (SK01) has only one bottleneck (cultural support), and a 0.13 unit (11.6\%) increase of the resources would boost Bratislava's REDI scores from 44.0 to 49.0. At the other end, the Hungarian Dél-Alföld (HU32) needs 0.61 units (23.8\%) for the same five-point REDI score increase. In order to achieve this goal, Dél-Alföld should improve 10 of its 14 pillars.

Whilst all regions have their unique entrepreneurship profile, there are some notable similarities. In general, globalization, high growth and process innovation do not represent bottlenecks for the CEE regions. This does not imply that these pillars are at a high level, but it means that they do not constrain the system of entrepreneurship as compared to other more binding pillars. Finance is the weak point of Estonia and of Hungarian regions except for the Budapest-centred KözépMagyarország. Opportunity perception is also relatively weak in most Hungarian regions. The lack of start-up skills characterizes the four Romanian regions. Networking is low in two Hungarian and in the four Romanian regions. Risk perception severely limits the Croatian, the Czech Republic, the Hungarian and the Slovenian regions. Human capital is relatively weak in Slovakia, in the Czech Republic, Croatia and in some Polish regions. High competition characterizes the Hungarian, the Slovakian, the Polish regions and the Czech Republic. The low level of product innovation constrains mainly the lower developed regions of Croatia, Hungary, Latvia, Lithuania, Romania and Slovakia. Cultural support and opportunity start-up are lacking in many CEE regions. These pillars can be viewed as general CEE macro-regional constraints of entrepreneurship.

\section{Summary and Conclusion}

Whilst entrepreneurship is believed to have a positive influence on national and regional economic development, traditional, start-up or self-employment-based entrepreneurship measures failed to reinforce this effect. A recently created new composite indicator, the Global Entrepreneurship Index (GEI) was the first measure of entrepreneurship to incorporate the influence of environmental factors on individual entrepreneurial initiative in a single setup. REDI is an amended version of GEI, measuring the entrepreneurship system of a region. 
Northern and Western European, mainly highly urbanized national, regions have the best entrepreneurial performance, and CEE regions can be found only in the lower half of the rankings. There are few CEE regions which reach the European regional average of pillar values. We have suggested that entrepreneurship plays a relatively small role in regional development in the CEE regions since their REDI scores are generally below the development-implied trend line. The deviation between the actual and the implied REDI scores is highest-in absolute terms - in the most developed, capital city-dominated CEE regions. These central, highly urbanized regions should have a much higher level of entrepreneurship than they actually do.

We have demonstrated that the overall entrepreneurial performance of the CEE regions is below that of the other two, SE and the NWE macro-regions. The SE and CEE regions lag behind the NWE regional average in all three subindices. This finding simply reinforces previous study results regarding transitional country development paths. However, the NWE and the SE regions have similar scores in all three subindices. At the same time, the CEE regions are less balanced. To clarify the differences and similarities further, we used a cluster analysis technique based on the 14 pillars and representing the entrepreneurship ecosystem. We found that CEE country regions tend to cluster together-as do SE and former East German regions. One cluster comprises only CEE regions including Polish regions, the Czech Republic and Bratislavský kraj.

Besides notable similarities, CEE country regions differ significantly in terms of the configuration of their 14 pillars. In general, CEE regions are relatively strong in entrepreneurial aspirations-related pillars (high growth, globalization and process innovation), although there are some problems in the entrepreneurship abilities (mainly in opportunity start-up and competition). In fact, the high ratio of necessitymotivated start-ups could explain the low level of the most problematic pillar-that is, opportunity start-up. History-related factors, the heritage of the old socialist system, could be responsible for the generally low level of entrepreneurial attitudes. In particular, start-up skills are low in many CEE regions, and culture does not really support entrepreneurs.

Looking more closely at the 29 CEE regions' entrepreneurial profiles, we can confirm that each region requires a unique tailor-made policy instead of a uniform, 'one-size-fits-all' approach. Our policy suggestions are based on the assumption that system performance can be improved most effectively by alleviating systemconstraining bottlenecks. A simulation aiming to improve the REDI scores by five points produced an optimal allocation of additional resources over the 14 pillars of entrepreneurship for each of the 29 CEE regions. We should stress, however, that the results of this exercise should not be used directly as entrepreneurship policy recommendation. In fact, this simulation is only a starting point for a much more comprehensive examination and facilitation process (Autio and Levie 2015; Estonia Report 2015).

Acknowledgement This project has received funding from the European Union's Horizon 2020 research and innovation programme under grant agreement No. 649378 (the 'FIRES' project). The article reflects the views of the authors only, and neither the agency nor the Global Entrepreneurship Monitor is responsible for any use which may be made of the information it contains. 


\section{References}

Acs, Z. J. (2010). Entrepreneurship and regional development. Cheltenham: Edward Elgar.

Acs, Z. J., Audretsch, D. B., \& Strom, R. (2009). Entrepreneurship, growth and public policy. Cheltenham: Edward Elgar.

Acs, Z. J., Autio, E., \& Szerb, L. (2014). National systems of entrepreneurship: Measure issues and policy implications. Research Policy, 43(3), 476-494.

Acs, Z. J., Desai, S., \& Hessels, J. (2008). Entrepreneurship, economic development and institutions. Small Business Economics, 31(3), 219-234.

Acs, Z. J., \& Mueller, P. (2008). Employment effects of business dynamics: Mice, gazelles and elephants. Small Business Economics, 30(1), 85-100.

Audretsch, D. B., \& Fritsch, M. (2002). Growth regimes over time and space. Regional Studies, 36 (2), 113-124.

Autio, E., \& Levie, J. (2015). Management of entrepreneurial ecosystems. Mimeo: Imperial college Business School.

Bateman, M. (2000). Neo-liberalism, SME development and the role of Business Support Centres in the transition economies of Central and Eastern Europe. Small Business Economics, 14(4), 275-298.

Baumol, W. J. (1996). Entrepreneurship: Productive, unproductive, and destructive. Journal of Business Venturing, 11(1), 3-22.

Blažek, J., \& Netrdová, P. (2012). Regional unemployment impacts of the global financial crisis in the new member states of the EU in Central and Eastern Europe. European Urban and Regional Studies, 19(1), 42-61.

Braunerhjelm, P., Acs, Z. J., Audretsch, D., \& Carlsson, B. (2010). The missing link. Knowledge diffusion and entrepreneurship in endogenous growth. Small Business Economics, 34(2), $105-125$.

Carree, M. A., \& Thurik, R. (2003). The impact of entrepreneurship on economic growth. In Z. J. Acs \& D. B. Audretsch (Eds.), Handbook of entrepreneurship research (pp. 437-471). Boston: Kluwer.

Carree, M., Van Stel, A., Thurik, R., \& Wennekers, S. (2002). Economic development and business ownership: an analysis using data of 23 OECD countries in the period 1976-1996. Small Business Economics, 19(3), 271-290.

Chepurenko, A. (2015). Entrepreneurial activity under 'transition'. In R. Blackburn, U. Hytti, \& F. Welter (Eds.), Context, process and gender in entrepreneurship: Frontiers in European entrepreneurship research (pp. 6-22). Cheltenham: Edward Elgar.

Estrin, S., Meyer, K. E., \& Bytchkova, M. (2006). Entrepreneurship in transition economies. In M. Casson, B. Yeung, A. Basu, \& N. Wadeson (Eds.), The Oxford handbook of entrepreneurship (pp. 693-725). Oxford: Oxford University Press.

Estrin, S., \& Mickiewicz, T. (2011). Entrepreneurship in transition economies: The role of institutions and generational change. In M. Minniti (Ed.), The dynamics of entrepreneurship: Evidence from the global entrepreneurship monitor data (pp. 181-208). Oxford: Oxford University Press.

Feldman, M. P. (2001). The entrepreneurial event revisited: Firm formation in a regional context. Industrial and Corporate Change, 10(4), 861-891.

Fritsch, M., \& Schmude, J. (Eds.). (2006). Entrepreneurship in the Region, ISEN International Studies in Entrepreneurship. New York: Springer.

Furerlinger, G., Funke, T., \& Fandl, U. (2014). The role of the state in the entrepreneurial ecosystem: Insights from Germany. Triple Helix, 2(1), 1-26.

Global Entrepreneurship and Development Institute. (2015). Estonia report 2015. Towards a more entrepreneurial Estonia: Call for action. Accessed August 1, 2016, from https://thegedi.org/ estonia-regional-facilitation-report/ 
Henrekson, M., \& Johansson, D. (2011). Firm growth, institutions, and structural transformation. In M. Fritsch (Ed.), Handbook of research on entrepreneurship and regional development. National and regional perspectives (pp. 175-215). Cheltenham: Edward Elgar Publishers.

Kerr, W., \& Nanda, R. (2009). Finance constraints and entrepreneurship (NBER working paper 15498). Cambridge, MA.

Komlósi, É., Szerb, L., Acs, J. Z., \& Ortega-Argilés, R. (2015). Quality related regional differences in entrepreneurship based on the GEDI methodology: The case of Hungary. Acta Oeconomica, 69(3), 455-477.

Kornai, J. (1992). The principles of privatization in Eastern Europe. De Economist, 140(2), $153-176$.

Kornai, J. (2006). The great transformation of Central Eastern Europe. Economics of Transition, $14(2), 207-244$.

Lazear, E. P. (2004). Balanced skills and entrepreneurship. The American Economic Review, 94 (2), 208-211.

McMillan, J., \& Woodruff, C. (2002). The central role of entrepreneurs in transition economies. The Journal of Economic Perspectives, 16(3), 153-170.

Noseleit, F. (2013). Entrepreneurship, structural change, and economic growth. Journal of Evolutionary Economics, 23(4), 735-766.

Qian, H., Acs, Z. J., \& Stough, R. (2013). Regional systems of entrepreneurship: The nexus of human capital, knowledge, and new firm formation. Journal of Economic Geography, 13(4), $559-587$.

Sauka, A. (2008). Productive, unproductive and destructive entrepreneurship: A theoretical and empirical exploration (Vol. 3). Frankfurt am Main: Peter Lang.

Shane, S. (2009). Why encouraging more people to become entrepreneurs is bad public policy. Small Business Economics, 33(2), 141-149.

Smallbone, D., \& Welter, F. (2001). The distinctiveness of entrepreneurship in transition economies. Small Business Economics, 16(4), 249-262.

Smallbone, D., \& Welter, F. (2012). Entrepreneurship and institutional change in transition economies: The commonwealth of independent States, Central and Eastern Europe and China compared. Entrepreneurship and Regional Development, 24(3-4), 215-233.

Sokol, M. (2001). Central and Eastern Europe a decade after the fall of state-socialism: Regional dimensions of transition processes. Regional Studies, 35(7), 645-655.

Stam, E. (2007). Why butterflies don't leave: Locational behavior of entrepreneurial firms. Economic Geography, 83(1), 27-50.

Stangler, D., \& Bell-Masterson, J. (2015). Measuring an entrepreneurial ecosystem. Kauffman Foundation Research Series on City. Metro and Regional Entrepreneurship, Kauffman Foundation.

Stenholm, P., Acs, Z. J., \& Wuebker, R. (2013). Exploring country-level institutional arrangements on the rate and type of entrepreneurial activity. Journal of Business Venturing, 28(1), $176-193$.

Sternberg, R. (2011). Regional determinants of entrepreneurial activities - Theories and empirical design. In M. Fritsch (Ed.), Handbook of research on entrepreneurship and regional development. National and regional perspectives (pp. 33-57). Cheltenham: Edward Elgar Publishers.

Szerb, L., Acs, Z. J., \& Autio, E. (2013). Entrepreneurship and policy: The national system of entrepreneurship in the European Union and in its member countries. Entrepreneurship Research Journal, 3(1), 9-34.

Szerb, L., Acs, Z. J., Autio, E., Ortega-Argilés, R., \& Komlósi, É. (2014). REDI: The regional entrepreneurship and development index - Measuring regional entrepreneurship. Report for the European Commission Directorate-General Regional and Urban Policy. Accessed September 25, 2014, from http://ec.europa.eu/regional_policy/sources/docgener/studies/pdf/ regional_entrepreneurship_development_index.pdf

Szerb, L., \& Trumbull, W. N. (2016). The development of entrepreneurship in the European transition countries: Is transition complete? Strategic Change, 25(2), 109-129. 
Tyson, L. D. A., Petrin, T., \& Rogers, H. (1994). Promoting entrepreneurship in Eastern Europe. Small Business Economics, 6(3), 165-184.

van der Zwan, P., Verheul, I., \& Thurik, R. (2011). The entrepreneurial ladder in transition and non-transition economies. Entrepreneurship Research Journal, 1(2), 1-18.

Wennekers, S., \& Thurik, R. (1999). Linking entrepreneurship and economic growth. Small Business Economics, 13(1), 27-56.

Westlund, H., \& Bolton, R. (2003). Local social capital and entrepreneurship. Small Business Economics, 21(2), 77-113.

Wong, P. K., Ho, Y. P., \& Autio, E. (2005). Entrepreneurship, innovation and economic growth: Evidence from GEM data. Small Business Economics, 24(3), 335-350.

Zahra, S., \& Nambisan, S. (2011). Entrepreneurship in global innovation ecosystem. AMS Review, $1(1), 4-17$.

László Szerb is University Professor at the Faculty of Business and Economics of the University of Pécs. He obtained his Ph.D. in Economics from West Virginia University (USA) and became the Doctor of the Hungarian Academy of Sciences in 2012. His teaching focuses mainly on small business and entrepreneurship-related subjects. László Szerb is the Director of the Department of Management Sciences. Professor Szerb has been a Visiting Professor in Austria, Denmark, Finland, Ireland, Italy, and the United States. He has published extensively in entrepreneurship topics including the determinants of entrepreneurship, competitiveness and performance. In the last years, he has focused his research on entrepreneurship indicator methodology, being one of the main creators together with Zoltán J. Ács of the Global Entrepreneurship and Development Index. Professor Szerb is the Director of the International Ph.D. Program in Regional Development.

Éva Komlósi holds a Ph.D. in Economics from the University of Pécs (2014). In her dissertation, she investigated various issues related to contemporary regional development policy in Japan. In 2010, she won a 2-year Japanese state-financed scholarship to carry out research in Japan. Since 2012 Dr. Komlósi has a position in the MTA-PTE Innovation and Economic Growth Research Group at the University of Pécs. She has recently participated in a major EU-financed research project, which focused on the construction of the regional GEDI entrepreneurship index (REDI). Her current main area of research is the investigation of the effects of institutional factors on entrepreneurship.

Balázs Páger graduated in Economics (M.Sc.) at the University of Pécs in 2010, and he is working as junior research fellow for the Institute for Regional Studies Centre for Economic and Regional Studies Hungarian Academy of Sciences. He has been doing his doctoral studies at University of Pécs. He has taken part in various research projects regarding measuring regional and national entrepreneurship, identifying development paths in Central and Eastern European regions and determining the regional innovation processes in Hungary. His research interests concern regional entrepreneurship, innovation processes and regional development. 